Agro-Science Journal of Tropical Agriculture, Food, Environment and Extension Volume 20 Number 2 (April 2021) pp. $81-85$

ISSN 1119-7455

\title{
SEASONAL VARIATION OF ENTERIC BACTERIA POPULATION IN SURFACE WATER SOURCES AMONG RURAL COMMUNITIES OF IJEBU NORTH, OGUN STATE, NIGERIA
}

\author{
${ }^{* 1}$ Egberongbe H.O., ${ }^{2}$ Bankole M.O., ${ }^{2}$ Popoola T.O.S. and ${ }^{3}$ Olowofeso O. \\ ${ }^{1}$ Department of Microbiology, Faculty of Science, \\ Olabisi Onabanjo University, P.M.B. 2002, Ago-Iwoye, Ogun State, Nigeria \\ ${ }^{2}$ Department of Microbiology, College of Biological Sciences, \\ Federal University of Agriculture, P.M.B. 2204, Abeokuta, Ogun State, Nigeria \\ ${ }^{3}$ Department of Animal Breeding \& Genetics, \\ College of Animal Science \& Livestock Production, \\ Federal University of Agriculture, P.M.B. 2204, Abeokuta, Ogun State, Nigeria \\ *Corresponding author's email: bimpe.egberongbe@oouagoiwoye.edu.ng
}

\begin{abstract}
The study assessed the effect of seasonal variation on enteric bacteria population in water sources of six different communities between April 2017 and March 2018 using conventional microbiological methods. Bacteria belonging to the enteric family were primarily investigated in this study. The bacteriological analyses included total viable bacterial counts and phenotypic characterization. The bacteriological analyses showed that total heterotrophic counts ranged from $1.2 \times 10^{4} \mathrm{cfu} / \mathrm{ml}$ to $3.0 \times 10^{4} \mathrm{cfu} / \mathrm{ml}$ and from $1.0 \times 10^{4} \mathrm{cfu} / \mathrm{ml}$ to $2.0 \times 10^{4} \mathrm{cfu} / \mathrm{ml}$ during the dry and wet seasons, respectively. One hundred and twenty-two potentially pathogenic species of bacteria representing 10 genera were identified. These included Acinetobacter sp., Enterobacter sp., Escherichia coli, Shigella sp., Salmonella sp., and Proteus sp. Others are Serratia sp., Pseudomonas sp., Yersinia sp., and Klebsiella sp. Results showed that bacteria isolated (10) were higher during the rainy season while Klebsiella sp (24) and Enterobacter sp (30) were the predominant species. It was apparent that water sources investigated in this study were unsafe for domestic use due to the presence of these pathogenic bacteria. So, there is a need for the provision of safe water in these communities to prevent outbreaks of waterborne disease.
\end{abstract}

Key words: microbial, potable water, rural dwellers, seasonal variation

\section{INTRODUCTION}

Water is essential for the sustenance of life and good health (Owamah, 2020). The significance of its quality to human physiology and the continuous existence of humans can not be undermined (Onweluzo and Akuagbazie, 2010). However, waterborne diseases remain a constant public health concern which ominously distresses the level of global morbidity and mortality (Jamal et al., 2020). About 1.1 billion people do not have access to safe water and this has been linked to diarrhea, a major waterborne disease, which has been reported to cause 1.6 million attributable deaths and 74.4 million disability-adjusted life per annum, respectively (Jamal et al., 2020). Incidence of waterborne diseases consequentially arises with the presence of pathogens, particularly of fecal origin, in water for consumption and other essential purposes (Jamal et al., 2020). However, quantification of the true burden of waterborne diseases can be challenging, generating evidence on risks related to contamination of water sources can be a grim task particularly in low and middle-income countries (Cissé, 2019).
In many low and middle-income countries, the prospect of water-borne diseases is high due to inadequate infrastructure, lack of appropriate public health practice, and slow emergency response (Uprety et al., 2020). In sub-Saharan Africa, populations with deteriorating environments have been associated with the practice of open defecation, this increases the chances of waterborne diseaserelated outbreaks within such population owing to contamination of water sources by pathogens of fecal origins such as Escherichia coli which causes diarrhea (Gwimbi et al., 2019). About $33 \%$ of the Nigerian population lacks access to improved water sources; besides poor sanitation and inadequate hygiene, this population is vulnerable to disease outbreak caused by waterborne pathogens (Ayandiran et al., 2018).

In rural communities, provision to safe water is of great concern, access to basic amenities such as clean water supply and good sanitation is inadequate, this, without doubt, leads to the search of water from other available sources such as streams, rivers, and wells (Egberongbe et al., 2012).

Please cite as: Egberongbe H.O., Bankole M.O., Popoola T.O.S. and Olowofeso O. (2021). Seasonal variation of enteric bacteria population in surface water sources among rural communities of Ijebu North, Ogun State, Nigeria. Agro-Science, 20 (2), 81-85. DOI: https://dx.doi.org/10.4314/as.v20i2.13 
While the level of dependency on surface water in these communities remains exceedingly high, These sources are nonetheless prone to contamination at point and non-point sources caused by infiltration, leaching, surface runoff through pastures, improper sewage systems, and uncontrolled effluent discharge (Malik et al., 2012; Akinnibosun and Ayejuyoni, 2015; Daramola et al., 2019). Poor water quality is considerably accountable for disease outbreaks in these communities (Malik et al., 2012). Therefore, It is logical to assess the surface water used by these communities to identify various risk factors of relative importance to water-borne diseases (Prüss-Ustün et al., 2019). Considering that unacceptable levels of bacteria should not be present in water for drinking and other essential purposes, an assessment of the bacterial population present in water would not only provide insights into the pathogenic potential and general quality of the water but would also show the various species of the bacterial community as well as the level of contamination of the water source (Pedersen et al., 2019).

Generally, the assessment of bacteria and broader microbial activity in water used by rural communities have been carried out by various researchers in Nigeria (Ayandiran et al., 2018; Fakayode and Ogunjobi, 2018; Daramola et al., 2019; Bebeteidoh et al., 2020; Jagaba et al., 2020; Owamah, 2020). This study was carried out to critically assess the bacteria population present in surface water in the rural communities studied and the significance of seasonal variation on the microbial status of the surface water.

\section{MATERIALS AND METHODS \\ Sample Collection}

The sampling area was located at Ijebu-North Local Government in Ogun State, Nigeria. Its headquarters are in the town of Ijebu Igbo $6^{\circ} 57^{\prime} \mathrm{N}$ $4^{\circ} 00^{\prime} \mathrm{E}$. The rural communities sampled were selected based on the data obtained from the Water and Sanitation department of the local government. The selected communities include Mamu, Araromilooji, Odoye, Aba-baale, Tekunle-oga and Okenugbo. Mamu, Araromi-looji, Odoye and Ababaale had regular flowing streams which had soft sediments while Tekunle-oga and Okenugbo had low flowing streams with hard substrates. In terms of biological phenology, in the study area, April to September is considered the rainy season while October to March is considered dry season (Oluwalana et al., 1999). Samples were randomly collected at the stream site of the five different rural communities early in the morning, before abstraction by the residents, using an airtight sterile container. This was to provide microorganisms present in water with oxygen from each point and avoid contamination from the surrounding air.

\section{Physico-Chemical Analysis}

Analysis of taste, odour, and colour of water samples were carried out at the site of sample collection before immediate transportation to the laboratory for microbiological analysis (Fawole and Oso, 2001).

\section{Bacteriological Analysis}

Water samples were serially diluted $\left(10^{-6}\right)$ and were cultured aseptically in nutrient agar using the pour plate technique. All plates were incubated at $35^{\circ} \mathrm{C}$ for $24 \mathrm{~h}$. Following incubation, colony counts were carried out using a digital illuminated colony counter and was recorded in colony-forming units per milliliter (cfu/ml) (Bergey, 1939). Distinct colonies were then subcultured on MacConkey agar, Blood agar, Salmonella-Shigella agar, and Campylobacter agar for further identification using colonial and biochemical characterization as described in Bergey's Manual of Systematic bacteriology (Bergey, 1939).

\section{RESULTS}

Physico-chemical analysis of water samples was carried out during both rainy and dry seasons. During the rainy season, water samples obtained from Mamu, Okenugbo, Araomi-looji streams ranged from Slightly Muddy (Light Brown) to Muddy (Brown) whereas Odoye and Aba-baale streams, were highly muddy (Deep Brown), while Tekunle-oga was slightly clear due to the presence of particles. During the dry season, water samples from Mamu, and Araromi-looji were clear, water samples from Odoye, Okenugbo and Tekunle-oga were slightly clear due to the presence of particles while the water sample obtained from Aba-baale had a light yellow colour. All samples obtained in this study during both dry and rainy seasons were tasteless and odourless (Table 1).

Table 1: Physico-chemical parameters of water samples during rainy and dry seasons

\begin{tabular}{|c|c|c|c|c|}
\hline Location & Season & $\begin{array}{l}\text { Colour/ } \\
\text { Appearance }\end{array}$ & Odour & Taste \\
\hline \multirow[t]{2}{*}{ Mamu } & Rainy & $\begin{array}{l}\text { Slightly Muddy } \\
\text { (Light Brown) }\end{array}$ & \multirow{12}{*}{$\begin{array}{l}\frac{u}{0} \\
\stackrel{0}{\Xi} \\
\frac{0}{0}\end{array}$} & \multirow{12}{*}{ 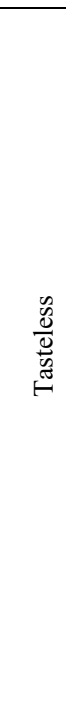 } \\
\hline & Dry & Clear & & \\
\hline \multirow{2}{*}{$\begin{array}{l}\text { Araromi- } \\
\text { looji }\end{array}$} & Rainy & Muddy (Brown) & & \\
\hline & Dry & Clear & & \\
\hline \multirow[t]{2}{*}{ Odoye } & Rainy & $\begin{array}{l}\text { Very Muddy } \\
\text { (Deep Brown) }\end{array}$ & & \\
\hline & Dry & $\begin{array}{l}\text { Slightly Clear } \\
\text { has particles }\end{array}$ & & \\
\hline \multirow[t]{2}{*}{ Okenugbo } & Rainy & $\begin{array}{l}\text { Slightly Muddy } \\
\text { (Light Brown) }\end{array}$ & & \\
\hline & Dry & $\begin{array}{l}\text { Slightly Clear } \\
\text { has particles }\end{array}$ & & \\
\hline \multirow[t]{2}{*}{$\begin{array}{l}\text { Tekunle- } \\
\text { oga }\end{array}$} & Rainy & $\begin{array}{l}\text { Slightly Clear } \\
\text { has particles }\end{array}$ & & \\
\hline & Dry & $\begin{array}{l}\text { Slightly Clear } \\
\text { has particles }\end{array}$ & & \\
\hline \multirow[t]{2}{*}{ Aba-baale } & Rainy & $\begin{array}{l}\text { Very Muddy } \\
\text { (Deep Brown) }\end{array}$ & & \\
\hline & Dry & Light yellow & & \\
\hline
\end{tabular}


The total viable counts of bacteria colonies were obtained from all samples which reveals the presence of bacteria at varying loads (Table 2). The total viable bacteria count of the water samples during the rainy season ranged from $3.20 \times 10^{4}$ $\mathrm{cfu} / \mathrm{ml}$ obtained from water sample belonging to Araromi looji in June to $1.10 \times 10^{4} \mathrm{cfu} / \mathrm{ml}$ obtained from water sample belonging to Tekunke-Oga in the month of April. During the dry season, the total viable count of the water samples ranged from 2.70 $\times 10^{4} \mathrm{cfu} / \mathrm{ml}$ obtained from Araromi looji in the month of October to $1.00 \times 10^{4} \mathrm{cfu} / \mathrm{ml}$ obtained from Odoye in the month of March. The microbial load of each study area varied with each month of sample collection. During the rainy season, microbial load of Mamu samples ranged from $1.86 \times 10^{4} \mathrm{cfu} / \mathrm{ml}$ (September) to $1.20 \times 10^{4} \mathrm{cfu} / \mathrm{ml}$ (April); Araromi looji samples ranged from $3.20 \times 10^{4} \mathrm{cfu} / \mathrm{ml}$ (June) to $1.96 \times 10^{4}$ (May); Odoye samples ranged from $2.80 \times 10^{4} \mathrm{cfu} / \mathrm{ml}$ (September) to $2.00 \times 10^{4} \mathrm{cfu} / \mathrm{ml}$ (April); Okenugbo samples ranged from $1.42 \times 10^{4}$ $\mathrm{cfu} / \mathrm{ml}$ (September) to $1.06 \times 10^{4} \mathrm{cfu} / \mathrm{ml}$ (April); Tekunle-oga samples ranged from $2.20 \times 10^{4} \mathrm{cfu} / \mathrm{ml}$ (July and August) to $1.10 \times 10^{4} \mathrm{cfu} / \mathrm{ml}$ (April); Ababaale samples ranged from $1.92 \times 10^{4} \mathrm{cfu} / \mathrm{ml}$ (September) to $1.16 \times 10^{4} \mathrm{cfu} / \mathrm{ml}$ (May). During the dry season, microbial load of Mamu samples ranged from $1.50 \times 10^{4} \mathrm{cfu} / \mathrm{ml}$ (October) to $1.02 \times 10^{4}$ $\mathrm{cfu} / \mathrm{ml}$ (March); Araromi looji samples ranged from
$2.70 \times 10^{4} \mathrm{cfu} / \mathrm{ml}$ (October) to $1.02 \times 10^{4}(\mathrm{March})$; Odoye samples ranged from $2.00 \times 10^{4} \mathrm{cfu} / \mathrm{ml}$ (October and November) to $1.00 \times 10^{4} \mathrm{cfu} / \mathrm{ml}$ (March); Okenugbo samples ranged from $1.38 \times 10^{4}$ $\mathrm{cfu} / \mathrm{ml}$ (October) to $1.02 \times 10^{4} \mathrm{cfu} / \mathrm{ml}$ (March); Tekunle-oga samples ranged from $1.82 \times 10^{4} \mathrm{cfu} / \mathrm{ml}$ (October) to $1.09 \times 10^{4} \mathrm{cfu} / \mathrm{ml}$ (March); Aba-baale samples ranged from $1.82 \times 10^{4} \mathrm{cfu} / \mathrm{ml}$ (December) to $1.20 \times 10^{4} \mathrm{cfu} / \mathrm{ml}$ (February and March).

Subsequently, using standard identification procedure with the aid of biochemical and morphological characterization. 54 isolates from 10 bacteria species belonging to the Enterobacteriaceae family were obtained from samples during this study. Klebsiella sp and Enterobacter sp were found to be the most occurring bacteria while Proteus sp was the least occurring bacteria (Table 3). While Klebsiella sp and Enterobacter sp were most occurring in rainy and dry seasons respectively, Proteus sp and Serratia sp were the least occurring bacteria in rainy and dry seasons, respectively. It was also observed that Mamu had the highest range of bacteria species, while the lowest range was observed in Aba-baale (Table 4). However, given each season, Araromilooji and Aba-baale had the highest and the lowest range in the rainy season while Tekunle-oga and the trio of Araromi-looji, Aba-baale, and Odoye had the highest and lowest range in the dry season.

Table 2: Microbial load of water samples during rainy and dry seasons

\begin{tabular}{|c|c|c|c|c|c|c|c|c|c|c|c|c|}
\hline \multirow[t]{2}{*}{ Study Area } & \multicolumn{6}{|c|}{ Rainy $\left(10^{4} \mathrm{cfu} / \mathrm{ml}\right)$} & \multicolumn{6}{|c|}{ Dry $\left(10^{4} \mathrm{cfu} / \mathrm{ml}\right)$} \\
\hline & Apr & May & Jun & July & Aug & Sept & Oct & Nov & Dec & Jan & Feb & Mar \\
\hline Mamu & 1.20 & 1.36 & 1.33 & 1.52 & 1.86 & 1.80 & 1.50 & 1.35 & 1.14 & 1.16 & 1.10 & 1.02 \\
\hline Araromi looji & 2.02 & 1.96 & 3.20 & 3.10 & 3.00 & 3.05 & 2.70 & 1.20 & 1.22 & 1.30 & 1.15 & 1.02 \\
\hline Odoye & 2.00 & 2.10 & 2.50 & 2.65 & 2.72 & 2.80 & 2.00 & 2.00 & 1.17 & 1.20 & 1.12 & 1.00 \\
\hline Okenugbo & 1.06 & 1.10 & 1.25 & 1.40 & 1.40 & 1.42 & 1.38 & 1.30 & 1.05 & 1.10 & 1.02 & 1.02 \\
\hline Tekunle-oga & 1.10 & 1.80 & 2.12 & 2,20 & 2.20 & 1.80 & 1.82 & 1.60 & 1.14 & 1.12 & 1.18 & 1.09 \\
\hline Aba-baale & 1.70 & 1.16 & 1.82 & 1.98 & 1.90 & 1.92 & 1.80 & 1.70 & 1.82 & 1.36 & 1.20 & 1.20 \\
\hline
\end{tabular}

Table 3: Seasonal prevalence of pathogenic microorganism

\begin{tabular}{|c|c|c|c|}
\hline \multirow{2}{*}{ Isolates } & \multicolumn{2}{|c|}{ Seasonal prevalence } & \multirow{2}{*}{ Overall prevalence } \\
\hline & Rainy & Dry & \\
\hline Salmonella sp. & $8.3 \%(5 / 60)$ & $4.8 \%(3 / 62)$ & $6.5 \%(8 / 122)$ \\
\hline Escherichia coli & $10 \%(6 / 60)$ & $12.9 \%(8 / 62)$ & $11.5 \%(14 / 122)$ \\
\hline Serratia $s p$ & $1.7 \%(1 / 60)$ & $1.6 \%(1 / 62)$ & $1.6 \%(2 / 122)$ \\
\hline Acinetobacter sp. & $10 \%(6 / 60)$ & $17.7 \%(11 / 62)$ & $13.9 \%(17 / 122)$ \\
\hline Shigella sp. & $10 \%(6 / 60)$ & $4.8 \%(3 / 62)$ & $7.3 \%(9 / 122)$ \\
\hline Klebsiella sp. & $26.7 \%(16 / 60)$ & $12.9 \%(8 / 62)$ & $19.7(24 / 122)$ \\
\hline Pseudomonas sp. & $5 \%(3 / 60)$ & $3.2 \%(2 / 62)$ & $4.1 \%(5 / 122)$ \\
\hline Yersinia sp. & $5 \%(3 / 60)$ & $14.5 \%(9 / 62)$ & $9.8 \%(12 / 122)$ \\
\hline Enterobacter sp. & $21.7 \%(13 / 60)$ & $27.4 \%(17 / 62)$ & $24.6 \%(30 / 122)$ \\
\hline Proteus sp. & $1.7 \% \quad(1 / 60)$ & $0 \%(0 / 62)$ & $0.8(1 / 122)$ \\
\hline
\end{tabular}

Table 4: Seasonal distribution of bacteria isolates across sample areas

\begin{tabular}{|c|c|c|c|c|c|c|c|c|c|c|c|c|}
\hline \multirow[b]{2}{*}{ Isolates } & \multicolumn{2}{|c|}{ Mamu } & \multicolumn{2}{|c|}{ Tekunle-oga } & \multicolumn{2}{|c|}{ Araromi-looji } & \multicolumn{2}{|c|}{ Aba-baale } & \multicolumn{2}{|c|}{ Odoye } & \multicolumn{2}{|c|}{ Okenugbo } \\
\hline & $\mathrm{R}$ & $\mathrm{D}$ & $\mathrm{R}$ & $\mathrm{D}$ & $\mathrm{R}$ & $\mathrm{D}$ & $\mathrm{R}$ & $\mathrm{D}$ & $\mathrm{R}$ & $\mathrm{D}$ & $\mathrm{R}$ & $\mathrm{D}$ \\
\hline Salmonella sp. & + & + & + & + & + & - & - & - & - & - & + & - \\
\hline Escherichia coli & + & - & + & + & - & - & + & + & - & + & - & - \\
\hline Serratia sp. & + & - & - & - & - & - & - & - & - & - & - & + \\
\hline Acinetobacter sp. & + & - & - & - & + & + & - & - & + & + & - & + \\
\hline Shigella sp. & + & + & + & + & + & - & - & - & + & - & + & - \\
\hline Klebsiella sp. & + & + & + & + & + & - & + & - & + & - & + & - \\
\hline Pseudomonas sp. & - & - & + & + & + & + & - & - & - & - & - & - \\
\hline Yersinia sp. & - & + & - & - & + & + & - & + & + & - & - & + \\
\hline Enterobacter sp. & - & + & + & + & + & - & - & + & - & + & + & + \\
\hline Proteus sp. & - & - & - & - & - & - & + & - & - & - & - & - \\
\hline
\end{tabular}

R - Rainy, D - Dry. Key: Present (+), Absent (-) 


\section{DISCUSSION}

Our study examined the enteric bacteria community present in surface water serving as a major source of domestic water in the selected rural communities. The significance of this microbial community should not be overlooked due to their pathogenic which might cause outbreaks of water-borne diseases. However, seasonal changes might influence the bacteria community structure present in the stream water, which is not surprising and supports previous findings (Bucci et al., 2014; Ren et al., 2019).

The microbiological, chemical and physical constituents of water affect its overall quality, hence it affects its taste, odour, or colour. However, according to WHO, highly turbid or coloured water having an objectionable odour or taste is very unsafe and should be prohibited (WHO, 2017). On this note, the samples obtained in this study were labeled unsafe due to the expression of colour and turbidity. Even though, they were all odourless and tasteless. The presence of fecal contaminants also observed in this study opposes the WHO guidelines on safe water, although this finding is consistent with some previous studies such as Divya and Solomon (2015) and Neher et al. (2020), water sources remain unpleasant for domestic use, therefore ensuring the safety of water sources in this community should be highly prioritized (Divya and Solomon, 2016; WHO, 2017; Neher et al., 2020).

The impact of seasonal dynamics on the bacteria community was analyzed in this study. Changes in seasons have an impact on bacteria population and composition as a result of multiple environmental pressures and this has been proven by various studies exploring the impact of seasonal changes on bacteria community in diverse ecosystems (Kaevska et al., 2016; Wang et al., 2019; Yadav et al., 2019). Therefore, obtaining seasonal samples allowed the analysis of the bacteria population during each season. Comparative analysis of the microbial load of different seasons observed in this study revealed the highest microbial load during the rainy season, this is consistent with the findings of similar studies carried out by Sun et al. (2017) and Yadav et al. (2019). Notably, cooler temperatures and increased water flow might make the bacteria favour the rainy season over the dry season. The dry season may expose the bacteria to frequent desiccation which may consequently result in the reduction of growth rate.

Palpably, the enteric bacteria family which also functions as fecal indicators was primarily investigated in this study. In recent times, the impact of seasonal variation on the presence of enteric bacteria in water used for drinking and other domestic purposes has been investigated in different environments. Ten members of this family were identified and characterized from samples obtained from the surface water sources investigated from this study. These findings are in concord with previous studies carried out by Tripathi et al. (2011),
Diwan et al. (2018), Kumpel et al. (2017) and Yadav et al. (2019); where the impact of seasonal variation on enteric bacteria was also observed. Enterobacter $s p$ and Klebsiella $s p$ were observed to be the most predominant species in the rainy and dry seasons respectively. These organisms have been reported in previous studies as frequent contaminants of water sources and can be used to indicate the potential health risks attributable to their pathogenic potentials (Podschun et al., 2001; Dwivedi et al., 2013; Barati et al., 2016; Price and Wildeboer, 2017; Onyango et al., 2018). The presence of enteric bacteria which functions as indicators of fecal pollution demonstrates the level of contamination of the water sources used by the rural communities studied, treatment of water sources, and disease prevention strategies should be carried out to avert the future potential of outbreaks.

Seasonal variations have an impact on the bacteria population but other factors such as nutrient composition, $\mathrm{pH}$, rate of pollution among other factors could influence the bacteria population. Also, the molecular methods which were not used in this study would have provided more accuracy during bacteria identification and characterization.

\section{CONCLUSION}

The surface water sources of the rural communities examined in this study were contaminated with bacteria of fecal origins particularly during the rainy season. These fecal contaminants have high pathogenic potential and cause diseases such as diarrhea, which could lead to a disease outbreak in rural communities where these water sources are situated. Therefore, from the findings of this study, the water sources should be treated to provide safe water to these rural communities. Alternatively, other sources of water with assured safety should be provided for rural communities.

\section{REFERENCES}

Akinnibosun F. and Ayejuyoni T. (2015). Assessment of microbial population and physico-chemical properties of abattoir effluent-contaminated soils in Benin City, Nigeria. Agro-Science, 14 (3), 1-6

Ayandiran T.A., Fawole O.O. and Dahunsi S.O. (2018). Water quality assessment of bitumen polluted Oluwa River, South-Western Nigeria. Water Resources and Industry, 19, 13-24

Barati A., Ghaderpour A., Chew L.L., Bong C.W. and Thong K.L. (2016). Isolation and characterization of aquatic-borne klebsiella pneumoniae from tropical estuaries in Malaysia. Int. J. Environ. Res. Public Health, 13 (426), 1-16

Bebeteidoh O.L., Kometa S., Pazouki K. and Norman R. (2020). Sustained impact of the activities of local crude oil refiners on their host communities in Nigeria. Heliyon, 6 (6), e04000. https://doi.org/https:// doi.org/10.1016/j.heliyon.2020.e04000

Bergey H. (1939). Bergey's Manual of Determinative Bacteriology. Bergey H., Breed R. and Murray E. (eds.); 5th ed., Wilkins \& Williams 
Bucci J.P., Szempruch A.J., Caldwell J.M., Ellis J.C. and Levine J.F. (2014). Seasonal changes in microbial community structure in freshwater stream sediment in a North Carolina River Basin. Diversity, 6, 18-32. https://doi.org/10.3390/d6010018

Cissé G. (2019). Food-borne and water-borne diseases under climate change in low- and middle-income countries: Further efforts needed for reducing environmental health exposure risks. Acta Tropica, 194, 181-188. https://doi.org/https://doi.org/10.1016/ j.actatropica.2019.03.012

Daramola J.M. Ekhwan T., Adepehin E.J., Mokhtar J., Lam K.C. and Er A.C. (2019). Seasonal quality variation and environmental risks associated with the consumption of surface water: implication from the Landzun Stream, Bida Nigeria. Heliyon, 5 (7), e02121. https://doi.org/https://doi.org/10.1016/j.heliyon.2019.e02121

Divya A.H. and Solomon P.A. (2016). Effects of some water quality parameters especially total coliform and fecal coliform in surface water of Chalakudy River. Procedia Technology, 24, 631-638. https://doi.org/10.1016/j.protcy.2016.05.151

Dwivedi D. Mohanty B.P. and Lesikar B.J. (2013). Estimating Escherichia coli loads in streams based on various physical, chemical, and biological factors. Water Resources Research, 49 (5), 2896-2906. https://doi.org/10.1002/wrcr.20265

Egberongbe H.O., Bello O.O., Solate A.T. and Sossou M.S. (2012). Microbiological evaluation of stream water for domestic use in rural areas : a case study of Ijebu North Local Government, Ogun State. Nigeria. J. Natural Sci, Engineering Technol., 11 (1), 93-103

Fakayode I.B. and Ogunjobi A.A. (2018). Quality assessment and prevalence of antibiotic resistant bacteria in government approved mini-water schemes in Southwest, Nigeria. Int. Biodet. Biodegrad., 133, 151-158. https:// doi. org/https://doi.org/10.1016/j. ibiod.2018.07.004

Fawole M. and Oso B. (2001). Laboratory Manual of Microbiology: Revised Edition. Spectrum Books Ltd.

Gwimbi P., George M. and Ramphalile M. (2019). Bacterial contamination of drinking water sources in rural villages of Mohale Basin, Lesotho: exposures through neighbourhood sanitation and hygiene practices. Environ. Health Preventive Med., 24 (1), 33. https://doi.org/10.1186/s12199-019-0790-z

Jagaba A.H., Kutty S.R.M., Hayder G. et al. (2020). Water quality hazard assessment for hand dug wells in Rafin Zurfi, Bauchi State, Nigeria. Ain Shams Eng. J., 11 (4), 983-999. https://doi.org/10.1016/j.asej.2020.02.004

Jamal R., Mubarak S., Sabulka S. et al. (2020). Informing water distribution line rehabilitation through quantitative microbial risk assessment. Sci. Total Environ., 739, 140021. https://doi.org/10.1016/j.scitotenv.2020.140021

Kaevska M., Videnska P., Sedlar K. and Slana I. (2016). Seasonal changes in microbial community composition in river water studied using 454-pyrosequencing. SpringerPlus, 5, 409. https://doi.org/10.1186/s40064-016-2043-6

Malik A., Yasar A., Tabinda A. and Abubakar M. (2012). Water-borne diseases, cost of illness and willingness to pay for diseases interventions in rural communities of developing countries. Iranian J. Public Health, 41 (6), 39-49. https://pubmed.ncbi.nlm.nih.gov/23113192

Neher T.P., Ma L., Moorman T.B. and Soupir M.L. (2020). Seasonal variations in export of antibiotic resistance genes and bacteria in runoff from an agricultural watershed in Iowa. Sci. Total Environ., 738, 140224 1-23. https://doi.org/10.1016/j.scitotenv.2020.140224
Oluwalana S.A., Ezeri G.N.A., Bankole M.O. and Bamire E.O. (1999). Uses of forest plants in traditional water management in Ogun State, Nigeria. The Bioprospector, 1 (1), 43-54

Onweluzo J. and Akuagbazie C. (2010). Assessment of the quality of bottled and sachet water sold in Nsukka town. Agro-Science, 9 (2), 104-110

Onyango A.E., Okoth M.W., Kunyanga C.N. and Aliwa B.O. (2018). Microbiological quality and contamination level of water sources in Isiolo County in Kenya. J. Environ. Public Health, Vol. 2018, Article ID 2139867, 10 pp. https://doi.org/10.1155/2018/2139867

Owamah H.I. (2020). A comprehensive assessment of groundwater quality for drinking purpose in a Nigerian rural Niger delta community. Groundwater Sustainable Dev, 10, 100286. https://doi.org/ https://doi.org/10.1016/j.gsd.2019.100286

Pedersen L., Rojas-tirado P., Arvin E. et al. (2019). Aquacultural engineering assessment of microbial activity in water based on hydrogen peroxide decomposition rates. Aquacultural Engineering, 85, 9-14. https://doi.org/10.1016/j.aquaeng.2019.01.001

Podschun R., Pietsch S., Höller C. and Ullmann U. (2001). Incidence of Klebsiella species in surface waters and their expression of virulence factors. Applied Environ. Microbiol., 67 (7), 3325-3327.https://doi.org/10.1128/ AEM.67.7.3325-3327.2001

Price R. and Wildeboer D. (2017). E. coli as an indicator of contaminationand health risk in environmental waters. In: Samie A. (ed.), Escherichia coli - Recent Advances on Physiology, Pathogenesis and Biotechnological Applications. Intech Open

Prüss-Ustün A., Wolf J., Bartram J. et al. (2019). Burden of disease from inadequate water, sanitation and hygiene for selected adverse health outcomes: An updated analysis with a focus on low- and middleincome countries. Int. J. Hygiene Environ. Health, 222 (5), 765-777. https://doi.org/https://doi.org/ 10.1016/j.ijheh.2019.05.004

Ren Z., Qu X., Zhang M., Yu Y. and Peng W. (2019). Distinct bacterial communities in wet and dry seasons during a seasonal water level fluctuation in the largest freshwater lake (Poyang Lake) in China. Frontiers in Microbiology, 10, 1107. https://doi.org/10.3389/ fmicb.2019.01167

Uprety S., Dangol B., Nakarmi P. et al. (2020). Assessment of microbial risks by characterization of Escherichia coli presence to analyze the public health risks from poor water quality in Nepal. Int. J. Hygiene Environ. Health, 226, 113484. https://doi.org/ 10.1016/j.ijheh.2020.113484

Wang Y., Liu Y., Wang J. et al. (2019). Seasonal dynamics of bacterial communities in the surface seawater around subtropical Xiamen Island, China, as determined by $16 \mathrm{~S}$ rRNA gene profiling. Marine Pollution Bulletin, 142, 135-144. https://doi.org/ 10.1016/j. marpolbul.2019.03.035

WHO (2017). Guidelines for Drinking-water (Fourth). World Health Organization

Yadav N., Singh S. and Goyal S.K. (2019). Effect of seasonal variation on bacterial inhabitants and diversity in drinking water of an office building, Delhi. Air, Soil Water Res., 12, 1-10. https://doi.org/10.1177/1178622119882335 